\title{
Incidence of Retromolar Foramen in Human Mandibles: Ethnic and Clinical Aspects
}

\author{
Incidencia del Foramen Retromolar en Mandibulas Humanas: Aspectos Étnicos y Clínicos
}

\author{
"Ana Cláudia Rossi; "Alexandre Rodrigues Freire; "Guilherme Bevilacqua Prado; "Felippe Bevilacqua Prado; \\ ${ }^{* *}$ Paulo Roberto Botacin \& *Paulo Henrique Ferreira Caria
}

ROSSI, A. C.; FREIRE, A. R.; PRADO, B. G.; PRADO, F. B.; BOTACIN, P. R. \& CARIA, P. H. F. Incidence of retromolar foramen in human mandibles: ethnic and clinical aspects. Int. J. Morphol., 30(3):1074-1078, 2012.

SUMMARY: The retromolar foramen allows the passage of the neurovascular bundles that contribute to nutrition and innervation of the pulp and periodontium of the lower teeth. Knowledge of this anatomical variation may prevent complications in the anesthesia and surgical procedures in this area and serve as an anatomical landmark for ethnic identification. The aim of this study was to evaluate the impact of the retromolar foramen in human mandibles of adult Brazilians and discuss the clinical and ethnic related to the presence of this foramen. Were evaluated 222 human mandibles, dry, adults, Brazilians, independent of gender. The evaluation was performed by two examiners who standardized search from a previous anatomical study. The mandibles were analyzed: the presence of the retromolar foramen (bilateral or unilateral), the presence of the foramen on right and left sides, and the number of foramens present on each side. It was found that 59 had at least one mandible retromolar foramens resulting in an incidence of $26.58 \%$. The retromolar foramen was present unilaterally in 41 mandibles and 18 bilaterally, with incidences of $18.47 \%$ and $12.16 \%$ respectively. On the right side, the retromolar foramen was present in incidences of $16.22 \%$ and $18.92 \%$ respectively. The analysis of the right side of the mandibles revealed that $47.46 \%, 21.21 \%$ and $3.03 \%$ had one, two and three foramens, respectively. The left side showed $55.93 \%, 16.22 \%$ and $8.11 \%$ of the 222 mandibles with one, two and three retromolar foramens, respectively. The incidence of retromolar foramen in the Brazilian population is significant and should be considered in the planning and execution of procedures in several areas of clinical practice dentistry in order to avoid complications. Moreover, it was found that the incidence of retromolar foramen contributes to differentiation of ethnic groups in the area of forensic anthropology.

KEY WORDS: Foramen; Retromolar; Anesthesia; Mandible.

\section{INTRODUCCIÓN}

Knowing the morphology of the human mandible and its possible variations is important for the planning of several procedures in the dental area as orthognathic surgery, mandibular reconstruction, extraction of third molars and installation of dental implants (Claeys \& Wackens, 2005).

The retromolar fossa, located between the anterior border of the mandible ramus and the temporal crest, may have one or more inconstant foramen called retromolar foramen, which permit the passage of vascular-nerve bundles that contribute to nutrition and innervation of the pulp and periodontium molar teeth (Sicher, 1960; Sawyer \& Kiely, 1991; Bilecenoglu \& Tuncer, 2006).

Ossenberg (1986) suggested that the frequency of the retromolar foramen varies according to ethnic factors. Thus, this author demonstrated the importance of this foramen as anatomical landmark of the mandible as differentiator between ethnic groups.

The presence of anatomical variations, such as the retromolar foramen, presents clinical implications, if not previously identified, can cause complications to clinical dental practice (Claeys \& Wackens). Furthermore, failures in the anesthesia by regional blockade of the inferior alveolar nerve are reported due to the presence of the retromolar foramen (Sawyer \& Kiely).

Given these considerations, the aim of this study was to evaluate the incidence of the retromolar foramen in Brazilians human mandibles and discuss the ethnic and clinical aspects related to the presence of this foramen.

\footnotetext{
* Department of Morphology, Anatomy Area, State University of Campinas - UNICAMP, Piracicaba, São Paulo, Brazil.

*** Department of Basic Sciences, Anatomy Area, Paulista State University - UNESP, Araçatuba, São Paulo, Brazil.
} 


\section{MATERIAL AND METHOD}

Were evaluated 222 Brazilians human mandibles, dry, adults, irrespective of gender. The evaluation was performed by two examiners who standardized the research from a previous anatomical study of the structure. Were observed concordance intra and inter-examiner for analysis of the foramen. The mandibles used belong to the laboratories of Anatomy of the Faculty of Dentistry of Araçatuba - Paulista State University (UNESP), SP, Brazil and of the Piracicaba Dental School - State University of Campinas (UNICAMP), SP, Brazil.

In the mandibles were evaluated: the presence of the retromolar foramen (bilateral or unilateral), the presence of the foramen on right and on left sides, and the number of foramen present on each side. Radiographs in the anatomic area of interest of the mandibles were made with purpose of illustration.

\section{RESULTS}

Was observed that 59 mandibles presented at least one retromolar foramens resulting in an incidence of $26.58 \%$ (Table I, Fig. 1). The retromolar foramen was present unilaterally in 41 mandibles and 18 bilaterally, with incidences of $18.47 \%$ and $12.16 \%$, respectively (Table I). On the right side, the retromolar foramen was present in 36 mandibles and the left side in 42 , resulting in incidences of $16.22 \%$ and $18.92 \%$, respectively (Table I).

In this study, were observed retromolar fossas with multiple foramens. The analysis of the right side of the mandibles revealed that $47.46 \%, 21.21 \%$ and $3.03 \%$ of 222 mandibles presented one, two and three were respectively

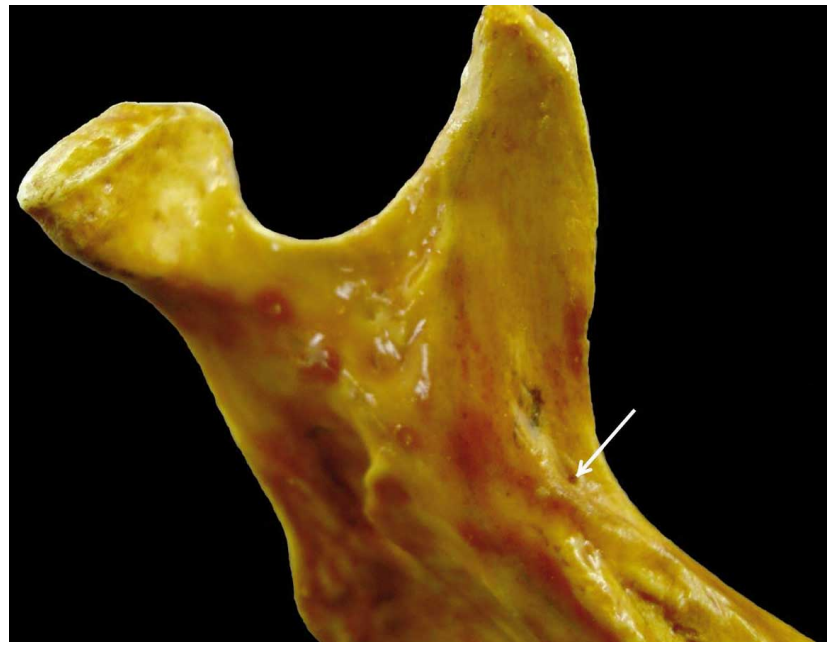

Fig. 1. Medial side of the mandible ramus. Observe the presence of a retromolar foramen in the retromolar fossa.

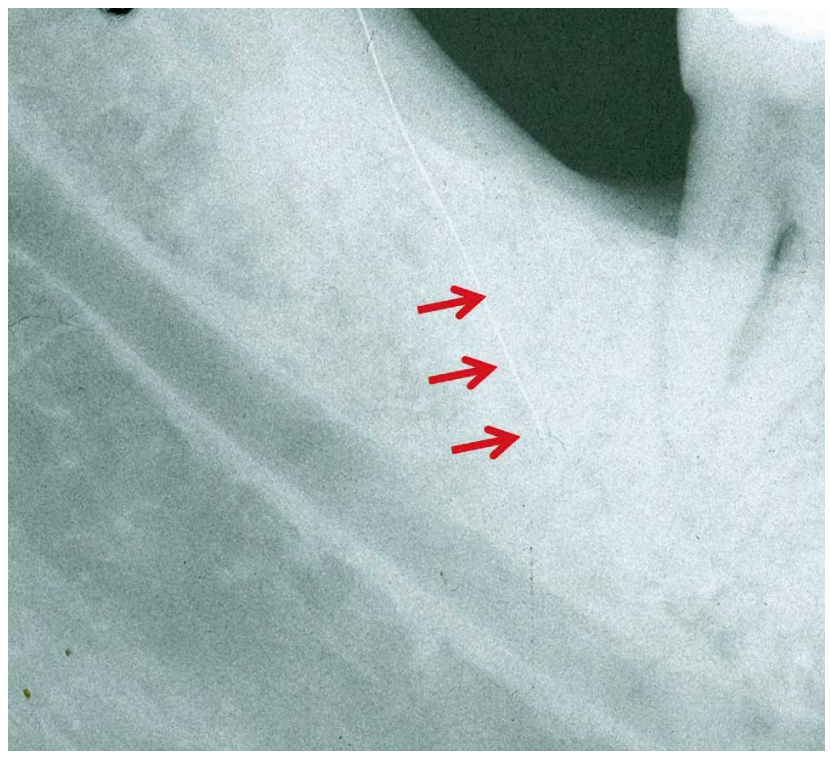

Fig. 2. Radiography of the retromolar area. A copper wire was inserted in the retromolar foramen to demonstrate the course of the retromolar canal (arrows indicate the copper wire).
Table I. Incidence (\%) of the retromolar foramen according to the side.

\begin{tabular}{ccccc}
\hline \multicolumn{5}{c}{ Incidence (\%) } \\
\hline Right side & Left side & Unilateral & Bilateral & Total \\
16.22 & 18.92 & 18.47 & 12.16 & 26.58 \\
$\mathrm{n}=18$ & $\mathrm{n}=36$ & $\mathrm{n}=42$ & $\mathrm{n}=41$ & $\mathrm{n}=59$ \\
\hline
\end{tabular}

Table II. Incidence (\%) of the retromolar foramen according to the number of foramen on each side.

\begin{tabular}{cccccc}
\hline \multicolumn{5}{c}{ Incidence (\%) } \\
\hline Right & \multicolumn{3}{c}{ Left } \\
\hline 1 foramen & $\mathbf{2 ~ f o r a m e n s ~}$ & 3 foramens & 1 foramen & 2 foramens & 3 foramens \\
\hline 47.46 & 21.21 & 3.03 & 55.93 & 16.22 & 8.11 \\
\hline
\end{tabular}

(Table II). The left side showed $55.93 \%, 16.22 \%$ and $8.11 \%$ of the 222 mandibles with one, two and three retromolar foramens, respectively (Table II).

Radiographic analysis revealed that the course of the retromolar canal is anterior inferior toward the alveolus of third molar. Note that the retromolar canal penetrates in the distal lamina dura of the distal root of the third molar (Figs. 2 and 3). 


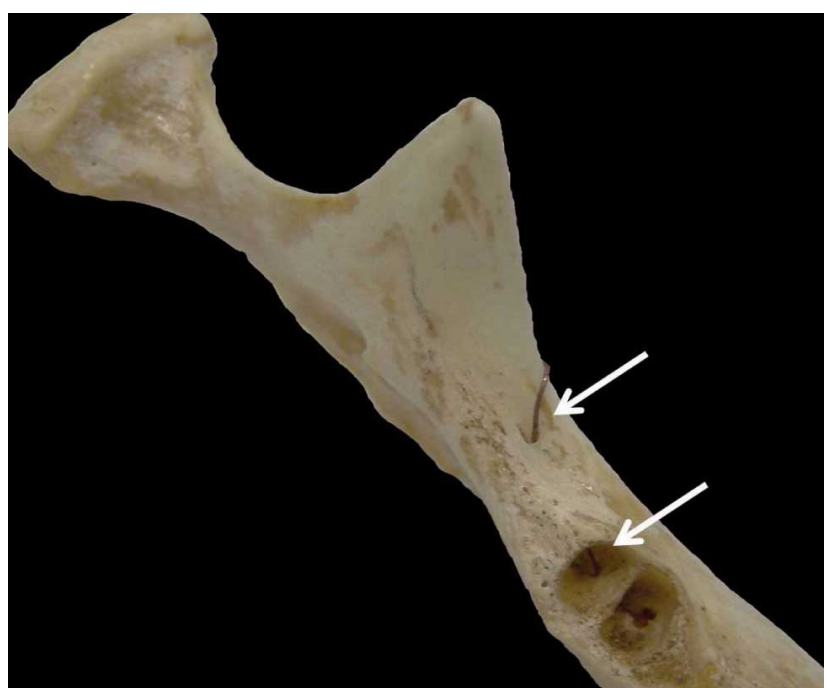

Fig. 3. Superior view of the retromolar fossa. A copper wire was inserted in the retromolar foramen to demonstrate the course of the retromolar canal to the alveolus of third molar (arrows indicate the copper wire).

\section{DISCUSSION}

The present study showed that the Brazilian population presented a significant incidence of retromolar foramen (26.58\%). Ossenberg (1987) examined mandibles of several world locations, including: Italy, while from 86 mandibles evaluated achieved an $8.1 \%$ incidence of retromolar foramen; in the Japan evaluated 94 mandibles achieved an incidence of $3.2 \%$; to analyze the mandibles of 485 Eskimos had $8.2 \%$ incidence of this foramen; 11 mandibles evaluated of Canadians of European descent with an incidence of $9.1 \%$. Ossenberg (1987) suggested that the populations of Latin America such as Argentina, Colombia and Brazil, were more likely to possess this foramen due to the heterogeneity of individuals as a result of the racial miscegenation. In addition, Ossenberg (1987) reported that the retromolar foramen is more frequent unilateral than bilaterally evaluated in mandibles these populations. A similar result obtained in this study that $18.47 \%$ of the mandibles showed the retromolar foramen unilaterally.

Other authors performed the incidence of this foramen in different populations, however, the Brazilian population evaluated in this study had a higher incidence. Narayana et al. (2002) showed that the incidence of retromolar foramen in the population of south India was $21.9 \%$. Bilecenoglu \& Tuncer evaluated 40 mandibles from population of Turkey and found the retromolar foramen in 10 , resulting an incidence of $25 \%$.
Anatomic variations of the mandible, as the retromolar foramen, may result in clinical complications if not properly identified, revealing the importance of studying the incidence of these variations (Pryia et al., 2005). Restoration of form and function without violating important anatomic structures is a fundamental goal in the surgical management of patient (Al-Khateeb et al., 2007).

Singh (1981), during surgery of a third molar, injured a nerve that crossed an unusual foramen located in the retromolar fossa. After the surgery, it was found that the patient presented paresthesia of the buccal mucosa from the retromolar region until the canine to the operated side. Tests of vitality were performed in the lower teeth, which responded positively. These tests prompted the author to affirm that the nerve injured it was a branch of the buccal nerve. However Kaufman et al. (2000) reported that the retromolar foramen for the passage of a neurovascular bundles from the inferior alveolar nerve and vessels.

Anderson et al. (1991) affirmed that the predominant components in the retromolar foramen and canal are nerves that provide innervation of the pulp of third molar, retromolar region, fibers of the temporalis and buccinator muscles.

Kaufman et al. affirmed that the presence of the neurovascular bundle present in the retromolar foramen and canal causes concern in clinical dentistry as during surgery for extractions of third molars or sagittal osteotomies of the mandible (Muto \& Kanazawa, 1997), because the retromolar neurovascular bundle allows the innervation and the nutrition of the buccal gingiva in the region of lower molar and retromolar region and may cause bleeding if injured (Kodera \& Hashimoto, 1995; Kaufman et al.; Wang et al., 2001). In addition, Pinsolle et al. (1997) suggested that because the retromolar canal also allow the passage of vascular components, may facilitate the spread of infection and metastases from the oropharynx. Perin et al. (2004) reported that the lesion of the vascular component of the retromolar canal during surgery for insertion of implants can produce bleeding, difficulting the incision and increasing the potential for formation of fibrous tissue in the area of contact with implant.

Scheitmann et al. (1967) analyzed 18 mandibles from cadavers and found the incidence of the retromolar foramen in $72 \%$. Were observed that the neurovascular bundle of foramen originated in the mandibular canal. These authors suggested that the high incidence of retromolar canal is due to genetic crossbreeding of European individuals with Aboriginal Argentineans. However, in the present study, the retromolar canal had a different traject. Was verified by radiograph analysis that from the retromolar foramen, the canal followed 
a traject anteroinferior penetrating into distal lamina dura of the distal root of the third molar (Fig. 2). It is suggested that the retromolar neurovascular bundle achieves this tooth to provide pulp innervation by lateral canals that finish into the root canal principal of the molar teeth. Thus, in the endodontic treatment, the clinician should be alert to the existence of lateral canals to the root canal due to the existence of accessory innervation provided by the retromolar canal (Madeira, 2010).

Sutton (1974) reported the presence of accessories foramen, including retromolar foramen in 300 human mandibles, which were crossed by additional sensory fibers. The author related the presence of this foramen to the failure to obtain analgesia from the classical anesthetic techniques and, moreover, confirmed the clinical significance of this observation through the study of anesthetic techniques in 130 patients. Thus, the study of the incidence of retromolar foramen is important in order to avoid failure in regional anesthetic techniques for blocking the inferior alveolar nerve and buccal nerve fibers due to accessory innervation that this foramen provides (Kodera \& Hashimoto; Kaufman et al.).

This study demonstrated that the incidence of retromolar foramen in the Brazilian population is significant and should be considered in the planning and execution of procedures in several areas of dental clinical practice in order to avoid complications. The accessory innervation caused by the presence of this foramen leads to failures in anesthesia techniques by regional block of the inferior alveolar and buccal nerves. Moreover, was found that the incidence of retromolar foramen contributes to differentiation of ethnic groups in the area of forensic anthropology.

\section{ACKNOWLEDGMENTS}

Special thanks for lab technician José Ari Gualberto Junqueira, Laboratory of Anatomy, Faculty of Dentistry of Araçatuba - UNESP and for lab technician Cristiano Manoel, Laboratory of Anatomy, Piracicaba Dental School - UNICAMP to having made available the mandibles used in this study.

ROSSI, A. C.; FREIRE, A. R.; PRADO, B. G.; PRADO, F. B.; BOTACIN, P. R. \& CARIA, P. H. F. Incidencia del foramen retromolar en mandíbulas humanas: aspectos étnicos y clínicos. Int. J. Morphol., 30(3):1074-1078, 2012.

RESUMEN: El foramen retromolar permite el paso de los haces neurovasculares que contribuyen a la nutrición y inervación de la pulpa y periodonto de los dientes mandibulares.
Conocer sus variaciones anatómicas pueden prevenir complicaciones de la anestesia y procedimientos quirúrgicos, y servir de punto de referencia anatómico para la identificación étnica. El objetivo de este estudio fue evaluar el impacto del foramen retromolar en mandíbulas humanas de brasileños adultos y discutir la relación clínica y étnica de la presencia de este foramen. Se evaluaron 222 mandíbulas humanas secas de adultos brasileños, independiente del sexo. La evaluación fue efectuada por dos examinadores que realizaron búsquedas estándar de un estudio anatómico anterior. En las mandíbulas se examinaron: la presencia del foramen retromolar (bilateral o unilateral), lados (derecho e izquierdo), y el número de forámenes presentes en cada lado. En 59 mandíbulas se observó al menos un foramen retromolar, una incidencia del 26,58\%. El foramen retromolar estuvo presente de manera unilateral en 41 mandíbulas, bilateralmente en 18 , con una incidencia del $18,47 \%$ y $12,16 \%$, respectivamente. En el lado derecho, el foramen retromolar estuvo presente en el 16,22\% y $18,92 \%$ respectivamente. El análisis de la parte derecha de la mandíbula reveló que $47,46 \%, 21,21 \%$ y $3,03 \%$ tuvo uno, dos y tres forámenes, respectivamente. El lado izquierdo mostró 55,93\%, $16,22 \%$ y $8,11 \%$ con uno, dos y tres forámenes retromolares, respectivamente. La incidencia del foramen retromolar en la población brasileña es significativo y se debe considerar en la planificación y ejecución de los procedimientos en varias áreas de la odontología clínica con el fin de evitar complicaciones. Por otra parte, se constató que la incidencia del foramen retromolar contribuye a la diferenciación de los grupos étnicos en el área de la antropología forense.

PALABRAS CLAVE: Forámen retromolar; Anestesia; Mandibula.

\section{REFERENCES}

Al-Khateeb, T.; Al-Hadi Hamasha, A. \& Ababneh, K. T. Position of the mental foramen in a northern regional Jordanian population. Surg. Radiol. Anat., 29(3):231-7, 2007.

Anderson, L. C.; Kosinski, T. F. \& Mentag, P. J. A review of the intraosseous course of the nerves of the mandible. J. Oral Implantol., 17(4):394-403, 1991.

Bilecenoglu, B. \& Tuncer, N. Clinical and Anatomical Study of Retromolar Foramen and Canal. J. Oral Maxillofac. Surg., 64(10):1493-7, 2006.

Claeys, V. \& Wackens, G. Bifid mandibular canal: literature review and case report. Dentomaxillofac. Radiol., 34(1):55-8, 2005.

Kaufman, E.; Serman, N. J. \& Wang, P. D. Bilateral mandibular accessory foramina and canals: A case report and review of the literature. Dentomaxillofac. Radiol., 29(3):170-5, 2000.

Kodera, H. \& Hashimoto, I. A case of mandibular retromolar canal: Elements of nerves and arteries in this canal. Kaibogaku Zasshi, 70(1):23-30, 1995. 
ROSSI, A. C.; FREIRE, A. R.; PRADO, B. G.; PRADO, F. B.; BOTACIN, P. R. \& CARIA, P. H. F. Incidence of retromolar foramen in human mandibles: ethnic and clinical aspects. Int. J. Morphol., 30(3):1074-1078, 2012.

Madeira, M. C. Anatomia do Dente. $6^{\mathrm{a}}$ ed. São Paulo, Sarvier, 2010.

Muto, T. \& Kanazawa, M. Mandibular reconstruction using the anterior part of the ascending ramus: Report of two cases. $J$. Oral Maxillofac. Surg., 55(10):1152-6, 1997.

Narayana, K.; Nayak U.A.; Ahmed, W. N.; Bhat, J. G. \& Devaiah, B. A. The retromolar foramen and canal in South Indian dry mandibles. Eur. J. Anat., 6(3):141-6, 2002.

Ossenberg, N. S. Retromolar foramen of the human mandible. Am. J. Phys. Anthropol,. 73(1):119-28, 1987.

Ossenberg, N. S. Temporal crest canal: Case report and statistics on a rare mandibular variant. Oral Surg. Oral Med. Oral Pathol., 62(1):10-2, 1986.

Perin, C. P.; Suzuki, A. M. M.; Fernandes, A.; Westphalen, F. H. \& Schussel, J. L. Importância das variações anatômicas dos canais mandibulares e suas implicações clínicas. JBC J. Bras. Clin. Odontol. Integr., 8(44):144-6, 2004.

Pinsolle, V.; Truilhé, Y.; Majoufre, C.; Michelet, V. \& Pinsolle, J. Posterior marginal mandibulectomy for cancer of the oral cavity and oropharynx. Experience with 14 clinical cases. Ann. Chir. Plast. Esthet., 42(3):223-7, 1997.

Priya, R.; Manjunath, K. Y. \& Balasubramanyam. Retromolar foramen. Indian J. Dent. Res., 16(1):15-6, 2005.

Sawyer, D. R. \& Kiely, M. L. Retromolar foramen: A mandibular variant important to dentistry. Ann. Dent., 50(1):16-8, 1991.

Schejtman, R.; Devoto, F. C. \& Arias, N. H. The origin and distribution of the elements of the human mandibular retromolar canal. Arch. Oral Biol., 12(11):1261-8, 1967.

Sicher, H. Oral Anatomy. 3rd ed. St. Louis, MO, Mosby, 1960.

Singh, S. Aberrant buccal nerve encountered at third molar surgery. Oral Surg. Oral Med. Oral Pathol., 52(2):142, 1981.

Sutton, R. N. The practical significance of mandibular accessory foramina. Aust. Dent. J., 19(3):167-73, 1974.

Wang, P. D.; Serman, N. J. \& Kaufman, E. Continious radiographic visualization of the mandibular nutrient canals. Dentomaxillofac. Radiol., 30(2):131-2, 2001.
Correspondence to:

DDS Ana Cláudia Rossi

Postgraduate Student

Av. Limeira, 901 P.O. Box: 52

Department of Morphology

State University of Campinas - UNICAMP

13414-903

Piracicaba, SP

BRAZIL

Email: anaclaudiarossi@fop.unicamp.br

Received: 29-04-2011

Accepted: 18-10-2011 